of the PLASMIC score for rapid assessment of adults with thrombotic microangiopathies: a cohort study. Lancet Haematol 2017;4:e157-e164.

2. George JN. How I treat patients with thrombotic thrombocytopenic purpura: 2010. Blood 2010;116:4060-4069.

3. Fromm LM. Suspected hydroxychloroquine-induced thrombotic thrombocytopaenic purpura. J Pharm Pract Res 2018;48:72-75.
4. Mar N, Mendoza Ladd A. Acquired thrombotic thrombocytopenic purpura: puzzles, curiosities and conundrums. J Thromb Thrombolysis 2011;31:119-121.

5. Naranjo CA, Busto U, Sellers EM, Sandor P, Ruiz I, Roberts EA, Janecek E, Domecq C, Greenblatt DJ. A method for estimating the probability of adverse drug reactions. Clin Pharmacol Ther 1981;30:239-245.

\title{
Sleeve Gastrectomy in a Severe Hemophilia A Patient: One of the Very Rare Cases
}

\section{Ağır Hemofili A Hastasında Sleeve Gastrektomi Operasyonu: Çok Nadir Olgulardan Biri}

\author{
(D) Eren Arslan Davulcu1, (D) Zühal Demirci1, (D) Özgür Fırat², (D) Güray Saydam¹, (D) Fahri Şahin ${ }^{1}$ \\ ${ }^{1}$ Ege University Medical Faculty, Hematology Department, Ege Adult Hemophilia and Thrombosis Center, Izmir, Turkey \\ 2Ege University Medical Faculty, Department of General Surgery, Izmir, Turkey
}

\section{To the Editor,}

Obesity is becoming a problem for aging hemophilia patients. The estimated prevalence of overweight and obesity in European and North American hemophilia patients is 31\% [1]. Similarly to non-hemophiliacs, excessive weight has an adverse effect on the cardiovascular system and the psychological and musculoskeletal health of hemophilia patients. Bariatric surgery is advised to be considered for patients from the general population with a body mass index (BMI) of $\geq 40$ $\mathrm{kg} / \mathrm{m}^{2}$ or BMI of $\geq 35 \mathrm{~kg} / \mathrm{m}^{2}$ with comorbidities [2]. Although it is not contraindicated, there are limited data on bariatric surgery among hemophilia patients. There are only two hemophilia A patients reported in the literature who had bariatric surgery. The first one underwent a successful sleeve gastrectomy [3] and the other had mini-gastric bypass surgery [4].

A 55-year-old severe hemophilia A patient with arterial hypertension, diabetes mellitus, hyperlipidemia, obstructive sleep apnea, and morbid obesity (BMI of $42.45 \mathrm{~kg} / \mathrm{m}^{2}$ ) decided to have obesity surgery because of inconclusive efforts at losing weight and obesity-related comorbidities. He had been receiving factor VIII prophylaxis at 6000 units/week for the last few years because conventional treatment at 4500 units/week was not sufficient for his frequent joint bleedings.
According to the Hemophilia Diagnosis and Treatment Guidelines of the Turkish Society of Hematology [5], the perioperative factor VIII target was calculated as 100\%. Three days before surgery, his factor VIII level was $2.3 \%$ and factor VIII inhibitor was negative. He received factor VIII at 42 units $/ \mathrm{kg}$ preoperatively and we planned to administer 23 units $/ \mathrm{kg}$ at the postoperative $12^{\text {th }}$ hour (weight: $130 \mathrm{~kg}$ ). At the postoperative $7^{\text {th }}$ hour he had hypotension, loss of consciousness, oliguria, $13 \%$ decline in hematocrit level, and increase in creatinine and transaminase levels. At that time, activated partial thromboplastin time (aPT) was $26.8 \mathrm{~s}$ (normal range: 22.531.3). During explorative laparotomy, approximately $500 \mathrm{~mL}$ of blood was drained from the abdominal cavity, but a surgical bleeding focus could not be found. Packing was performed according to damage control surgery principles. After $48 \mathrm{~h}$ the abdominal cavity was reopened for unpacking and no bleeding was observed. He was followed in the intensive care unit for the following 8 days with mechanical ventilation. He needed intermittent hemodialysis because of hemorrhage-related acute kidney injury. During this period, he had thrombocytopenia and prolonged prothrombin time. He had multiple erythrocyte, platelet, and fresh frozen plasma replacements due to probable disseminated intravascular coagulation. Hemorrhage from the surgical drains lessened and finally stopped. Perioperative laboratory results are summarized in Table 1. 


\begin{tabular}{|c|c|c|c|c|c|c|c|c|c|c|c|c|}
\hline & $\begin{array}{l}\text { Preop, } 3 \\
\text { days }\end{array}$ & $\begin{array}{l}\text { Postop } \\
7^{\text {th }} \text { hour }\end{array}$ & $\begin{array}{l}\text { Postop } 1^{\text {st }} \\
\text { day }\end{array}$ & $\begin{array}{l}\text { Postop } \\
2^{\text {nd }} \text { day }\end{array}$ & $\begin{array}{l}\text { Postop } \\
4^{\text {th }} \text { day }\end{array}$ & $\begin{array}{l}\text { Postop } \\
8^{\text {th }} \text { day }\end{array}$ & $\begin{array}{l}\text { Postop } \\
14^{\text {th }} \text { day }\end{array}$ & $\begin{array}{l}\text { Postop } \\
21^{\text {st }} \text { day }\end{array}$ & $\begin{array}{l}\text { Postop } \\
1^{\text {st }} \\
\text { month }\end{array}$ & $\begin{array}{l}\text { Postop } \\
2^{\text {nd }} \\
\text { month }\end{array}$ & $\begin{array}{l}\text { Postop } \\
3.5^{\text {th }} \\
\text { month }\end{array}$ & $\begin{array}{l}\text { Postop } \\
7^{\text {th }} \\
\text { month }\end{array}$ \\
\hline aPTा & 36.7 & 26.8 & 33.7 & 33.6 & 29.5 & 28.5 & 28.6 & 31.8 & - & - & 29.5 & - \\
\hline PT & 10.5 & 11.7 & 20.4 & 19.5 & 12 & 10.4 & - & 12 & - & - & 10.7 & - \\
\hline HCT & 44.1 & 29.4 & 36.3 & 25.2 & 22.7 & 22.8 & 23.3 & 25.4 & 24.2 & 31 & 38.1 & 38.6 \\
\hline PLT & 206000 & 314000 & 145000 & 96000 & 43000 & 136000 & 408000 & 275000 & 245000 & 209000 & 228000 & 146000 \\
\hline Urea & 38 & - & 39 & 74 & 47 & 64 & 78 & 82 & 156 & 16 & 28 & - \\
\hline $\mathrm{Cr}$ & 0.63 & - & 2.06 & 4.94 & 2.48 & 2.2 & 6.32 & 8.04 & 4.2 & 1.11 & 0.76 & - \\
\hline AST & 26 & - & 1649 & 1467 & 690 & 172 & 172 & 19 & 13 & - & 13 & - \\
\hline ALT & 68 & - & 2125 & 1714 & 1416 & 214 & 214 & 6 & $<5$ & - & 13 & - \\
\hline Fibr & - & - & 215 & 291 & - & - & - & - & - & - & - & - \\
\hline T.bil & 0.58 & - & 1.09 & 1.11 & 2.27 & 1.29 & 0.66 & 0.61 & - & - & - & - \\
\hline D.bil & 0.25 & - & 0.81 & 0.9 & 2.07 & 1.19 & 0.28 & 0.41 & - & - & - & - \\
\hline \multicolumn{13}{|c|}{ 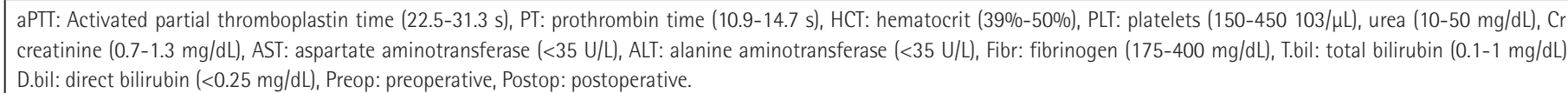 } \\
\hline
\end{tabular}

Factor VIII replacement was performed at 100\% level (42 units/ $\mathrm{kg} /$ day) until bleeding ceased for 8 days after surgery. The factor threshold was decreased to 60\% (30 units/kg/day) during the next 8 days and to 40\% (20 units/kg/day) the next 5 days, and then the patient was switched to prophylactic treatment (6000 units/week).

During follow-up in the inpatient clinic for the next 30 days, his need for high doses of factor VIII replacement diminished, his urine output increased, cytopenia and hemostatic problems resolved, and kidney and liver functions normalized.

At 7 months after surgery, he had lost $42 \mathrm{~kg}$ and his BMI was 28.7 $\mathrm{kg} / \mathrm{m}^{2}$. His blood pressure and glucose are now well controlled. We intend to reduce factor VIII prophylaxis to 4500 units/week when the ideal body mass is achieved.

To the best of our knowledge, we are reporting the second hemophilia A patient to have a sleeve gastrectomy operation. The course of the procedure was challenging but the patient survived without any permanent damage and has even already begun to see the benefits of losing weight. His unexpected bleeding a couple of hours after the operation could not be attributed to any manifest surgical reasons or hemostatic defects. However, we think that there were likely some microvascular and hemostatic deficiencies. Since it was not possible to measure the factor VIII level just before the operation, we did not know the factor level precisely. Although aPTT was in the normal range, the factor concentration may be below the target level during this procedure. Our experience shows that major surgical operations such as bariatric surgery can be complicated in hemophilia patients; therefore, it is necessary that all parts of the team providing hemophilia care cooperate together.

Keywords: Hemophilia A, Obesity, Bariatric surgery

Anahtar Sözcükler: Hemofili A, Obezite, Bariatrik cerrahi

Informed Consent: Obtained.

\section{Authorship Contributions}

Design: E.D.A., Z.D., F.Ş.; Data collection and processing: E.D.A, Z.D., Ö.F., G.S., F.Ş.; Writing: E.D.A.

Conflict of Interest: No conflict of interest was declared by the authors.

Financial Disclosure: The authors declared that this study received no financial support.

\section{References}

1. Wilding J, Zourikian N, Di Minno M, Khair K, Marquardt N, Benson G, Ozelo $M$, Hermans C. Obesity in the global haemophilia population: prevalence, implications and expert opinions for weight management. Obes Rev 2018;19:1569-1584.

2. Türkiye Endokrinolojive Metabolizma Derneği. Obezite Tanı ve Tedavi Kılavuzu. 8. Baskı. Ankara, Miki Matbaacılık San. ve Tic. Ltd. Şti., 2019.

3. Yerrabothala $\mathrm{S}$, McKernan L, Ornstein DL. Bariatric surgery in haemophilia. Haemophilia 2016;22:e232-e234. 
4. Plamper A, Goldmann G, Lingohr P, Horneff S, Dohmen J, Oldenburg $J$, Rheinwalt KP. First case of laparoscopic mini-gastric bypass for the treatment of morbid obesity in severe haemophilia A. Hamostaseologie 2019;39:208-210.
5. Türk Hematoloji Derneği. Hemaofili Tanıve Tedavi Kılavuzu. Sürüm 1, Temmuz 2011. Ankara, Türk Hematoloji Derneği, 2011.

${ }^{\circ}$ Copyright 2020 by Turkish Society of Hematology

Turkish Journal of Hematology, Published by Galenos Publishing House

\title{
A Novel Coincidence: Essential Thrombocythemia with Facioscapulohumeral Muscular Dystrophy
}

\author{
Yeni Bir Birliktelik: Esansiyel Trombositemi ve Fasioskapulohumeral Musküler Distrofi
}

\author{
(D) Ceren Hangül1, (D) Orhan Kemal Yücel2, (D) Aslı Toylu³, (D) Hilmi Uysal4, (D) Sibel Berker Karaüzüm¹ \\ ${ }^{1}$ Akdeniz University Faculty of Medicine, Department of Medical Biology and Genetics, Antalya, Turkey \\ ${ }^{2}$ Akdeniz University Faculty of Medicine, Department of Hematology, Antalya, Turkey \\ ${ }^{3}$ Akdeniz University Faculty of Medicine, Department of Medical Genetics, Antalya, Turkey \\ ${ }^{4}$ Akdeniz University Faculty of Medicine, Department of Neurology, Antalya, Turkey
}

\section{To the Editor,}

Essential thrombocythemia (ET) is a myeloproliferative disorder with elevated numbers of thrombocytes and facioscapulohumeral muscular dystrophy (FSHD) is the third most common dystrophy among all dystrophies. In this paper, we report a novel case of FSHD coinciding with ET.

The male FSHD patient was diagnosed at the age of 17 with difficulty of raising his arms. He had 4q35 D4Z4 repeat contraction. A neurological examination revealed positive facial involvement and scapula alata; right and left shoulder flexion $4+$; right forearm flexion $4+$; left forearm flexion $3+$; right and left hip flexion $4+$; remaining muscle strengths $5+$. Mild involvement and loss of power were seen in the extensor indicis, peroneal muscles, and abdominal muscles. When the patient was 67 years old, he was admitted to the hematology clinic with facial redness and increased platelet count $\left(1,200,000 / \mathrm{mm}^{3}\right)$ without hepatosplenomegaly.

Since myeloproliferative neoplasms (MPNs) are frequently related to somatic mutations of the JAK2, MPL, and CALR genes, the patient's blood sample was analyzed for the hot-spot mutations of these genes. The exon 10 region of the MPL gene was analyzed for p.W515K/L mutation and the exon 9 region of the $C A L R$ gene was analyzed for insertion/deletion mutations with PCR/sequencing methods. The exon 14 region of the JAK2 (Janus kinase 2) gene was investigated for p.V617F (c.1849G>T) mutation by quantitative real-time PCR using plasmids of wild type and mutant alleles. There was no mutation in the target regions of the MPL and CALR genes. In the exon 14 region of the JAK2 gene, p.V617F (c.1849G>T) mutation was detected with $28 \%$ allele burden (Figure 1).

His child was also investigated for the JAK2 p.V617F (c.1849G>T) mutation and was found to be negative. Finally, the patient was diagnosed with high-risk ET because of being aged $>60$ years with JAK2 mutation, and hydroxyurea and low-dose aspirin were started.

In this case, the presence of the JAK2 p.V617F mutation confirmed the diagnosis of ET. There has been no report on the co-occurrence of FSHD with MPNs including ET and JAK2 p.V617F mutation, and this is the first such case in the literature. Recently, a number of reports indicated that some germ-line DNA variants may predispose to MPNs with JAK2 p.V617F mutation [1].

FSHD patients are prone to develop other systemic diseases, especially malignancies [2], via re-expression of the DUX4 gene that allows cancer cells to escape immune surveillance [3]. In addition, myeloid cells (including thrombocytes) and skeletal 